\title{
Self-Efficacy, Teacher Leadership and Teacher Professionalism in Secondary School
}

\author{
Anisa Rara Tyaningsih ${ }^{1}$, Suryadi ${ }^{2}$, Desi Rahmawati ${ }^{3}$ \\ 1,2,3 Universitas Negeri Jakarta, Indonesia
}

anisararatyaningsih@gmail.com

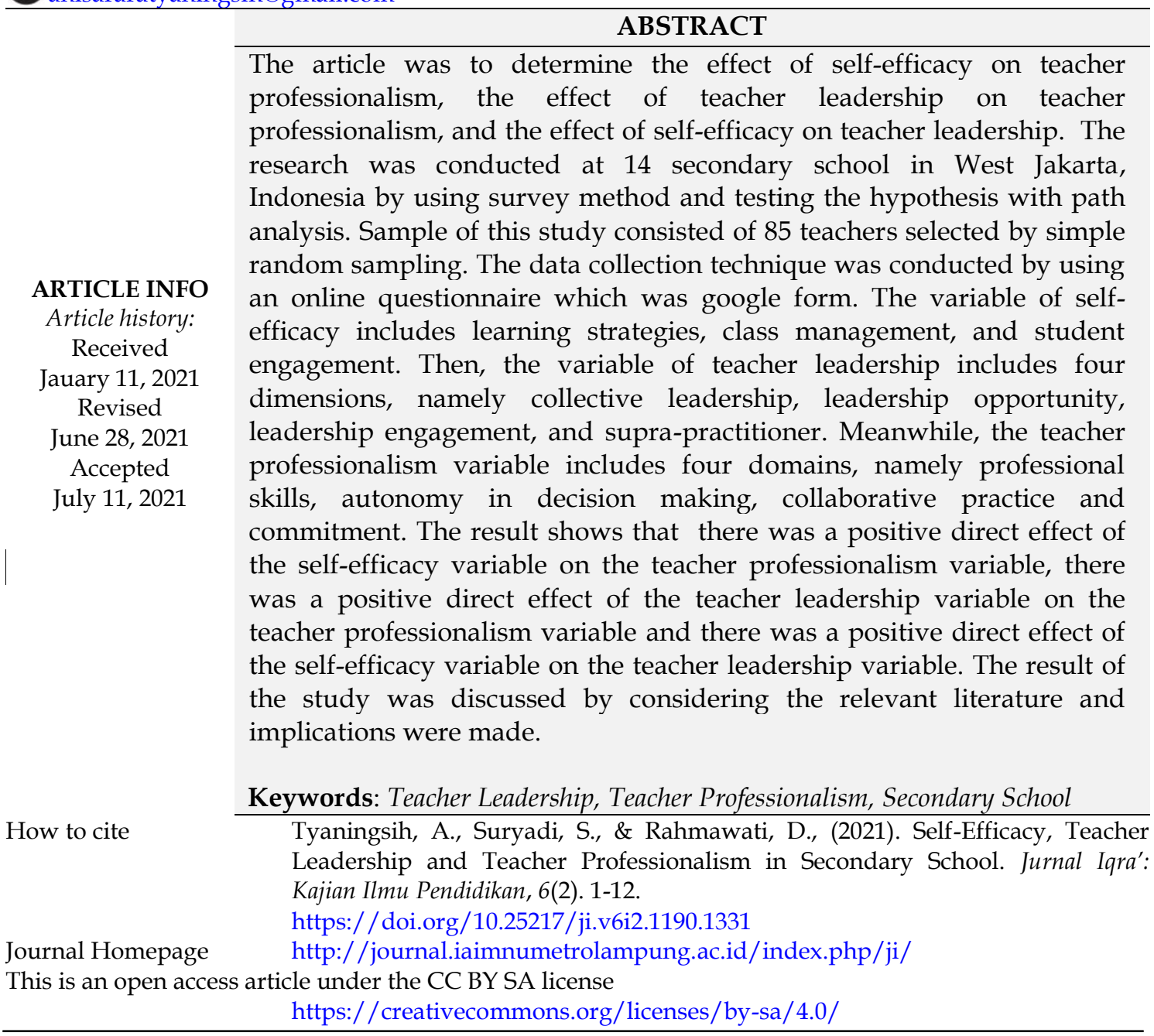

\section{INTRODUCTION}

Education is one aspect of measuring the success of a region's development. Through good and quality education, it is hoped that it can improve the quality of human resources. However data shows that there is no significant improvement of Indonesian student achievement during last decade based on Programme for International Student Assessment (PISA), Trends in International Mathematics and Science Study (TIMMS), and National Examination (UN) (Suharti, 2019). Teacher's quality might contribute for this case. Based on Uji Kompetensi Guru or Assessment of Teacher Competency (UKG) in 2019, teachers who teaching in West Jakarta area only get score 49.00 and 55.81 for pedagogical and professional competency (Kemendikbud, 2019). Professional characteristics which constitute the professional identity such as 
professional skills and pedagogical expertise known as professionalism (Fogelgarn et al., 2019).

Professionalism is defined as occupational or normative value and ideology (Evetts, 2014). Role of professional knowledge and skills, professional identity and occupational are significant for enhancing the professionalism for puclic trust (Avis \& Orr, 2014; Evetts, 2014; Mulder, 2014). Professionalism is built on collegial authority, which means that controls are guided by professional code of ethic that is supervised by professional association (Elkjaer \& Brandi, 2014). The characteristics are professional community development, autonomy, integrity, commitments, teamwork, and motivation that provide an orientation to thoughts and actions for decision-making in difficult conditions, rapid changes, and ethical challenges in a professional environment (Egener et al., 2017; Fogelgarn et al., 2019; Simons \& Ruijters, 2014). In other words, teacher professionalism is a practice and concept that is continously being changed and challenged as a result of internal and external demands (Sachs, 2016).

Professionalism focuses on cooperative and collaborative actions between teachers and educational stakeholders (Sachs, 2016). This view concerns on teachers professionalism through Continuing Professional Development (CPD). In short, Organisation for Economic Co-operation and Development (OECD) (2013) conclude that teacher professionalism indicates as the professional knowledge, skills, and practices that teachers must have in order to be successfull educators. Based on literatur above, teacher professionalism is the character of teachers to act in the best interests of students throughout their career based on teacher professional knowledge, autonomy of decision making, commintent and collaborative practice with fellow teachers or other educational stakeholders.

The literature explaines the significant of providing a professional, collaborative circumference where teachers can work towards shared expertise and learning (Demir \& Akif, 2015). In the study of Cansoy et al (2018), the results reveal that the domains of a supportive work environment and professional collaboration among the attributes of teacher leadership are significant predictors of teacher professionalism. Teacher leadership concept, was known as a essential tool for the education reforms and has integrated into teachers' professional practices (Kurt, 2016).

The definition of Teacher Leadership (TL) is related to the influence that teacher leaders have in their schools. York-Barr \& Duke (2004), introduced Theory of Action, states that TL is the process by which teachers, either individually or collectively, influence their colleagues, principals, and educational steakholders to foster teaching and learning practices with the purpose of improved student learning and achievement. TL is about influencing each other to enhance their own learning and fundamentally student learning through their collaborative practice and is represented as Spheres of Teacher Leadership Action for Learning (Fairman \& Mackenzie, 2015). Furthermore, TL is essentially an ethical stance grounded on the view of promoting students' life chances and on a belief in the power of the teaching profession to boost a difference in effective school outcomes (Pineda-Báez et al., 2020). In other words, TL in its true essence is considered as sostering leadership tasks and decision-making roles for teachers through working collectively without taking them out of the classrooms (Harris \& Jones, 2019; Jumani \& Malik, 2017).

Angelle \& Dehart (2016) designed The four-factor model of teacher leadership. These four factors are sharing leadership, principal selection, sharing expertise, and supra-practitionaire. In this case the school will be able to more successfully benefit from the valuable source of their teachers' expertise and experience (Demir \& Akif, 
2015). A school culture that fosters the professional development and teacher leadership is quite important. Based on the research, self-efficacy of teachers should be promoted to allow them to implement teacher leadership behaviors (Kurt, 2016).

Koşar (2015) said that there is positive significant relationship between teacher self-efficacy, trust in principals and teacher professionalism. According to Bandura (1993), self-efficacy is personal beliefs that they can successfully accomplish a task (Cansoy et al., 2018). The belief detemines their motivation, feeling, thought and behaviour. It affects self choice of activities, decision-making, and ability in perform a task (P. Angelle \& Teague, 2014; Cansoy et al., 2018). Then, Koşar (2015) explaines that self-efficacy is a examined in three domains as cognitive, affective and behavioral based on social cognitive theory. Furthermore, Shaukat and Iqbal (2012) and Sarfo et al (2015) explaines that the self-efficacy demonstrates teacher's belief that they can be effective at implementing instructional strategies, managing classroom and engaging students. Self-efficacy is also teachers' belief in self to reach goals and evaluate teaching effectiveness (P. Angelle \& Teague, 2014). Self-efficacy is nurtured by four different sources: verbal persuasion between principal and teachers, learning experience based on sharing expertise, mastery experience in teaching and emotional arousal (Fackler \& Malmberg, 2016). Teacher self-efficacy indicates as personal teachers' beliefs in their own capability to enact specific pedagogical practices that are required to enhance abilities and skills attain given educational purposes (Ninković \& Knežević Florić, 2018). In short, teacher's self-efficacy is the teacher's belief in their own ability to achieve student learning goals based on dimensions that include learning strategies, classroom management and student involvement.

Therefore, it is necessary to give more attention from the government, schools and the educational steakholder to deal with the problems of secondary school in West Jakarta City focus on teacher professionalism. We argue that high quality education is dependent on the potential within teacher professionalism. Within this case, when the related literature is examined, it has been seen that relationships between teacher professionalism and trust in principal, incentive, certification, teacher's satisfaction, status, motivation, and principal leadership (Habibi et al., 2019; Koşar, 2015; Lestari et al., 2019; OECD, 2016; Suyatno et al., 2019; Tschannen-Moran, 2009) and has been examined and hence some empirical findings were produced. This research developes previous research to determine the effect of self-efficacy and teacher leadership on teacher professionalism. The research context about teacher professionalism in West Jakarta and those variables is an interesting but an underexplored issue, too. We believe that, crucially, several variables indicated to have an effect on teacher professionalism, including: teacher leadership and self-efficacy. Therefore, the aim of this study is to determine 1) the effect of self-efficacy on teacher professionalism, 2) the effect of teacher leadership on teacher professionalism, and 3) the effect of self-efficacy on teacher leadership.

\section{METHODS}

This study uses a survey method with a quantitative approach. The endogenous variables in this study were teacher professionalism and the exogenous variables in this study were teacher leadership and self-efficacy variables. The population used in this study was taken based on the data of Neraca Pendidikan Daerah Jakarta Barat (NPD) in 2019. The total number of secondary school teachers is 535 civil servant (PNS) teachers of Secondary School will be used as the target population in this study. Then, the sample used in this study was taken using Slovin 
formula, 85 PNS teachers. Furthermore, the implementation of sample research using proportionate random sampling technique. This research was conducted by selecting a sample in terms of considering the proportion of the number of PNS teachers in each school in order to obtain the same proposition in the population.

There are some procedures in data analysis. They are: (1) validity using Pearson Product Moment formula. Validity criteria are indicated if the $\mathrm{r}$-count is representated in the corrected item-total correlation value greater than r-table. The score of r-table with a sample size 30 and significance level $5 \%$ is 0.361 (2) reliability using Alpha Cronbach formula. if the value of Cronbach Alpha is greater than 0.60 then it is reliable. (3) descriptive statistics (4) normality and significance of linear data (5) path analysis that are processed with the use of IBM SPSS Statistics 26.

This research used likert-scale questionnaire as data collection technique. The questionnaire was developed based on related literaturel review and consulted first with the supervisor to attain improvement. After getting approval from the supervisor, the instrument was tested on 30 respondents. Distribution of questionnaires were using google form. The validity and reability score of the instruments can be seen in Table 1.

Table 1 . Validity and Reability

\begin{tabular}{lcc}
\hline \multicolumn{1}{c}{ Variable } & Total Valid Items & Reability Score \\
& & \\
\hline Self Efficacy & 30 & 0,97 \\
\hline Teacher Leadership & 41 & 0,96 \\
\hline Teacher Professionalism & 30 & 0,95 \\
\hline
\end{tabular}

The experimental result shows that there are 30 items of self efficacy which are valid by the reability score of 0,97 . Then, there are 41 valid items of teacher leadership with reability score of 0,96 . Lastly, there are 30 valid items of teacher professionalism instrument with reability score of 0,95 . Based on these calculations, the instruments are valid and reliable so that it could be used for the research.

\section{RESULT AND DISCUSSION}

The result of descriptive analysis data can be seen in Table 2 .

Table 2. Descriptive Analysis

\begin{tabular}{lcc}
\hline \multicolumn{1}{c}{ Variable } & Mean & Standard Deviation \\
\hline Self Efficacy & 121,82 & 8,19 \\
\hline Teacher Leadership & 158,33 & 16,77 \\
\hline Teacher Professionalism & 125,24 & 7,91 \\
\hline
\end{tabular}

From the result of descriptive analysis, it can be seen that mean score of teacher leadership $(158,33)$ is the highest rather than the mean of teacher professionalism $(125,24)$ and self efficacy $(121,82)$. After that, the standard deviation of teacher leadership $(16,77)$ also the highest compared to other two variables. It happens because the total items of the teacher leadership (41) higher compared to the self efficacy and teacher professionalism which have only 30 items each. This first test conducted was to identify of normality and linearity data. The result of normality and significance of linear data can be seen in Table 3 
Table 3. Normality and Significane of Liniear Data Analysis

\begin{tabular}{|c|c|c|c|c|c|c|c|}
\hline \multirow[t]{2}{*}{ Analysis Data } & \multirow[t]{2}{*}{ Equation } & \multicolumn{2}{|c|}{ Normality } & \multicolumn{2}{|c|}{ Significance } & \multicolumn{2}{|c|}{ Linearity } \\
\hline & & $\mathrm{L}_{\text {score }}$ & $\mathrm{L}_{\text {table }}$ & $\mathrm{F}_{\text {score }}$ & $\mathrm{F}_{\text {table }}$ & $F_{\text {score }}$ & $\mathrm{F}_{\text {table }}$ \\
\hline $\begin{array}{l}\text { Self Efficacy }\left(\mathrm{X}_{1}\right) \text { and } \\
\text { Teacher } \\
\text { Professionalism }\left(\mathrm{X}_{3}\right)\end{array}$ & $\begin{array}{l}X_{3}=39,857+0 \\
, 701 X_{1}\end{array}$ & 0,039 & 0,096 & 91,90 & 3,85 & 1,12 & 1,67 \\
\hline $\begin{array}{l}\text { Teacher Leadership } \\
\left(\mathrm{X}_{2}\right) \text { and } \\
\text { Teacher } \\
\text { Professionalism }\left(\mathrm{X}_{3}\right)\end{array}$ & $\begin{array}{l}\mathrm{X}_{3}=72,938+0 \\
, 330 \mathrm{X}_{2}\end{array}$ & 0,083 & 0,096 & 79,63 & 3,84 & 1,29 & 1,68 \\
\hline $\begin{array}{l}\text { Self Efficacy }\left(\mathrm{X}_{1}\right) \text { and } \\
\text { Teacher Leadership } \\
\left(\mathrm{X}_{2}\right)\end{array}$ & $\begin{array}{l}X_{2}=-34,89+ \\
1,586 X_{1}\end{array}$ & 0,066 & 0,096 & 124,30 & 3,84 & 0,78 & 1,67 \\
\hline
\end{tabular}

Sample which is from population with normal distribution has $\mathrm{L}_{\text {score }}$ less than the $\mathrm{L}_{\text {table. }}$ Based on the table 3 above, by using Liliefors test, it can be seen that Lscore of self efficacy $\left(X_{1}\right)$ and teacher professionalism $\left(X_{3}\right)(0,039)$ is smaller compared to Ltable with total items more than 30 items which is 85 items and $a=0,05(0,0961002)$. It can be concluded that the sample was taken from the population with normal distribution. This also happens in teacher leadership $\left(X_{2}\right)$ and teacher professionalism $\left(X_{3}\right)$ regression with $L_{\text {score }}(0,083)$ and self efficacy $\left(X_{1}\right)$ and teacher leadership $\left(X_{2}\right)$ with $L_{\text {score }}$ $(0,066)$. It means that all sample of three variables were taken from the population with normal distribution.

Model of regression equation which is significant has $F_{\text {score }}$ greater than $F_{\text {table. }}$ As Table 3 is examined, significant regression is revealed out between self efficacy $\left(X_{1}\right)$ and teacher professionalism $\left(X_{3}\right)$ with greater $F_{\text {score }}(91,90)$ than $F_{\text {table }}(3,85)$. It can be said that the regression model is significant. Then by the result of teacher leadership $\left(X_{2}\right)$ and teacher professionalism $\left(\mathrm{X}_{3}\right)$ regression model with $\mathrm{F}_{\text {score }}(79,63)$ is greater than $\mathrm{F}_{\text {table }}$ $(3,84)$, the second regression is also significant. Same thing as previous, the self efficacy $\left(X_{1}\right)$ and teacher leadership $\left(X_{2}\right)$ regression model is also significant with $F_{\text {score }}(124,30)$ and $F_{\text {table }}(3,84)$. Furthermore, the regression models can be measured as linear model if the $\mathrm{F}_{\text {score }}$ smaller than $\mathrm{F}_{\text {table. }}$ Based on the table, it can be seen that all three regression models have $F_{\text {score }}$ smaller than $F_{\text {table. }}$. First regression model has $F_{\text {score }}(1,12)$ and $F_{\text {table }}$ $(1,67)$, second regression model has $F_{\text {score }}(1,29)$ and $F_{\text {table }}(1,68)$, and last regression model has $\mathrm{F}_{\text {score }}(0,78)$ and $\mathrm{F}_{\text {table }}(1,67)$.

The professionalism coefficient in the regression equation is 0,701 with selfefficacy and 0,330 with teacher leadership. This coefficient represents the mean score increase of self efficacy and teacher leadership for every additional one point in professionalism. These positive coefficients indicate that as the value of the independent variables which are self efficacy and teacher leadership increase, the mean of the dependent variable which is professionalism also tends to increase. After that, the second test conducted as prerequisite test of path analysis. It can be said that the data was satisfied the prerequisite test for path analysis. The result of path analysis can be seen in Table 4 . 
Table 4. Path Analysis

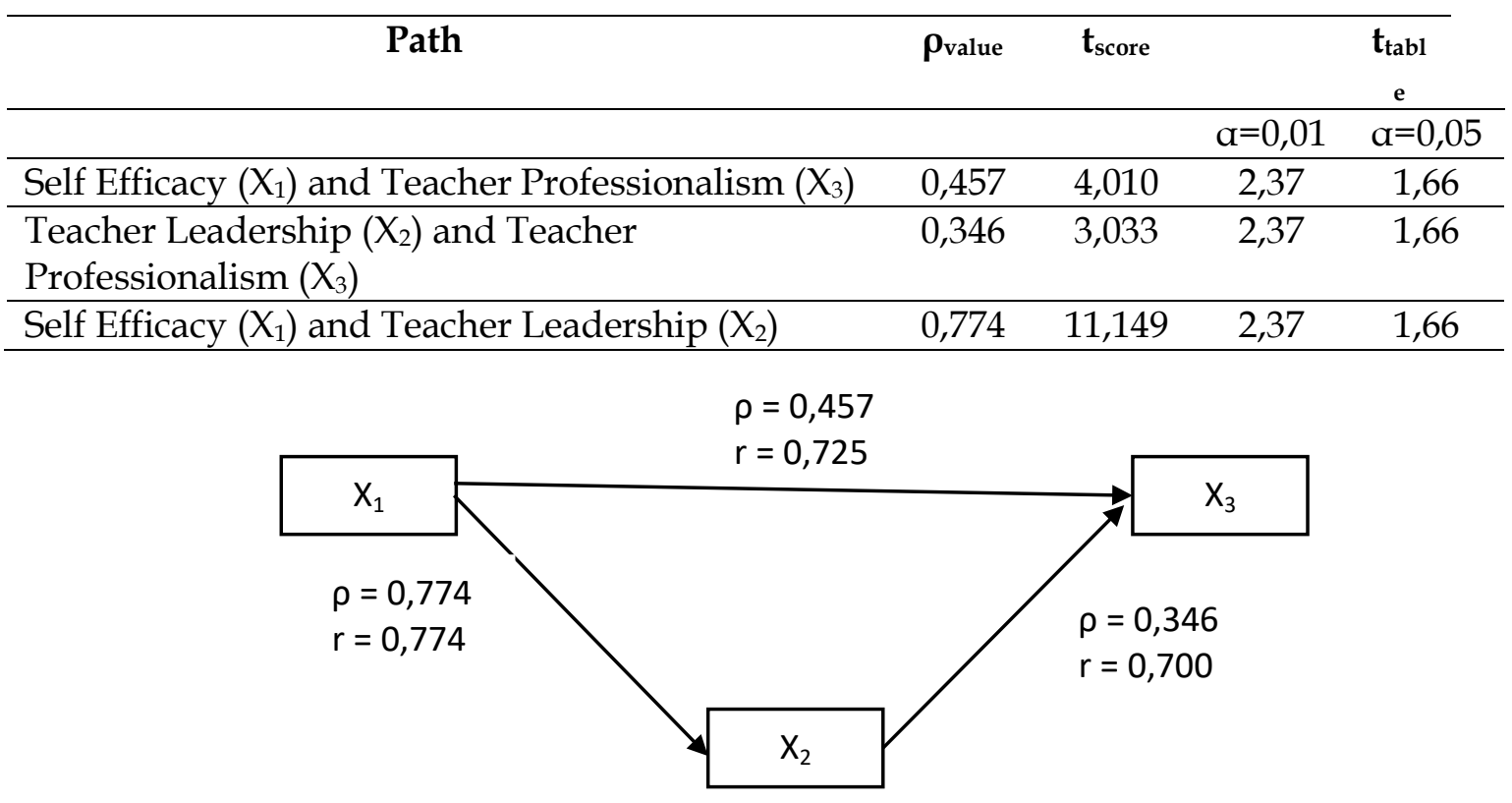

Picture 1. Path Analysis

First of all, the first hypothesis testing result can be concluded that there is a direct positive effect of self efficacy to teacher professionalism with the value of correlation coefficient of 0.725 and the path coefficient of 0.457 . This path also has greater $t_{\text {score }}(4,010)$ than $t_{\text {table }}$ with $\alpha=0,01$ and $\alpha=0,05(2,37$ and 1,66$)$. This gives the implication of self efficacy has direct positive effect on teacher professionalism.

According to the model developed in this study (Picture 1), a single-headed path diagram arrow points from cause to effect. It can be concluded that there is a direct positive effect of self efficacy to teacher professionalism. This result follows up the research which conducted by Koşar (2015) which describes that there is positive and significant relationship between teacher self-efficacy and teacher professionalism. In addition, the results reveal that teacher confidence level of self-efficacy is significant predictor of teacher professionalism.

Self efficacy detemines their feeling, motivation, thought and behaviour (Cansoy et al., 2018). Teachers believe in their own ability to achieve student learning goals based on dimensions that include learning strategies, classroom management and student involvement. Self efficacy is related to commitment for novice teachers, and furthermore, that level of commitment is related to captivate into the profession (Klassen \& Chiu, 2011). The occupational commitment influences the decision to gain the profession reinforces the significance of studying levels of occupational commitment. By maintaining their commitment to teaching advancement, it will be an active contributor to the conceptualization of professionalism (Fogelgarn et al., 2019). This view is in line with Egener et al (2017) that professionalism is asserted on a certain set of principles and commitments that give a belief to the thoughts and actions of a given profession.

Self efficacy influences professional decision-making processes (Singh et al., 2019). Self efficacy promotes an individual to gain personal mastery while giving compulsory strength to face adverse conditions and to fight and cope with stressful conditions, while motivating the teacher to face upcoming challenges in teaching and 
learning process. Furthermore, Koşar (2015) describes that the belief of teachers self efficacy that they can be successful by means of teaching practices they develop and practice to fulfill the students' learning needs may affect their professionalism in a positive way. It affects professional knowledge and skills, decision-making, commitment and practice in perform a professional work with patner. Hence, we believe that self-efficacy is a key driver of professionalism.

Secondly, from the results of the second hypothesis testing can be seen that there is a direct positive effect of teacher leadership to teacher professionalism with the value of correlation coefficient of 0.700 and the path coefficient of 0.346 . This path also has greater $t_{\text {score }}(3,033)$ than $t_{\text {table }}$ with $\alpha=0,01$ and $\alpha=0,05(2,37$ and 1,66$)$. This gives the meaning of teacher leadership has direct positive effect on teacher professionalism.

This result supports the research which was conducted by Cansoy et al (2018). The study reveals that attributes of teacher leadership are significant predictors of teacher professionalism. This result also sides with Lovett (2018) that teacher leadership exists in the pursuit of professional learning. Teacher leadership as a constructivism learning theory contributes collaborative and collective professional learning of teachers (Boyaci \& Oz, 2017). Teacher leadership is a leadership model inherent in teachers with collaborative and collective leadership practices with member in school communities, leadership in school progress operational activities, and leadership in professional practices. Then, this result also corresponds to Cansoy et al (2018), a significant predictor of teacher professionalism. Teacher leadership is more collective than individual task, and pedagogical. Teacher leadership development is somewhat dependent on the leader in the position of providing opportunities, giving support, and assessing the contribution of those closest to the classroom and student learning activities. The leadership role of teachers refers to professional learning to their own practice and that of others.

With the acceptance of the second hypothesis, an effort to foster teacher professionalism is to improve teacher leadership. Principals who wish to cultivate greater professionalism in their teacher behavior should consider a professional orientation in their leadership styles at the school level. Such development of teacher professionalism might in subsequent steps also contribute to an expansion of teacher leadership roles, which could contribute to promoting schools and functions in professional learning communities (PLC), where teams of teachers, from either one or different schools, continuously meet and critically interrogate and reflect on their leadership culture (Öqvist \& Malmström, 2018). By establishing organizational conditions in which teachers can implement greater teacher leadership to fulfill the needs of students, principals must give more attention to the professional values of schools, and inspiring teachers to appreciate their commitments to students. Principals must not only support but also challenge teachers to enhance the competencies necessary to accurately assess learners' needs and to make wise decisions in response to these assessments. A useful measure in this case involves developing skills for teachers to engage in joint planning for example, with a schedule to allow time for collaboration, communication, and peer coaching thus creating professional learning communities in schools.

As leaders, teachers influence individual, team and collaborative group development, and organizational capacity (eg, structures, policies, processes, resources) to promote effective teaching and learning in their schools (York-Barr \& Duke, 2004). This is part of the domain of professionalism, namely collaborative practice. Then, according to (Bush, 2015), quality of collaborative leadership makes a 
significant effectiveness. Therefore, it can be conclude that the facts shown by professional teacher behavior are associated with a school culture that promotes teacher leadership because a culture of collaborative practice provides collaborative learning, administrator support which encourages teachers to implement more learning methods and resources, and hence a supportive work environment can encourage teachers to take more responsibility for student learning process.

Thirdly, from the results of the third hypothesis testing can be concluded that there is a direct positive effect of self efficacy to teacher leadership with the value of correlation coefficient of 0.774 and the path coefficient of 0.457 . This path also has greater $t_{\text {score }}(4,010)$ than $t_{\text {table }}$ with $\alpha=0,01$ and $\alpha=0,05(2,37$ and 1,66$)$. This gives the meaning of self efficacy has direct positive effect on teacher leadership.

This finding corresponds to Kurt (2016) that self-efficacy positively affects teacher leadership behaviors of teachers in organizational development, professional development and collaboration among colleagues dimensions. Self-efficacy indicates teacher's belief that they can accomplish well at implementing instructional strategies, managing classroom and engaging students (Sarfo et al., 2015; Shaukat \& Iqbal, 2012).

Teachers with high level of self efficacy are resolved to cope with the problems without forsaking their goals and persevere even after they fail (Kurt, 2016). High teacher's self-efficacy level also gives a plus number of positive teaching results. Teachers who attain success with their students and who believe to have made a difference prove to be more successful in their professional career. This belief of the success motivates teachers to taking on further responsibilities in students' learning process. Thus, self-efficacy are required to promote professional knowledge and skills in order to attain given educational goals' (Ninković \& Knežević Florić, 2018). Improvement of teachers' working conditions involves improvement teachers' welfare programs such as provision of housing, quality meals, parties and trips and teachinglearning facilities can be strategies for enhancing teacher self efficacy (Odanga et al., 2018). The principal as leader who has the role facilitate the needs of teachers in teaching practices so that it will have an impact on the teaching efficacy of teachers (Ma'mun \& Suryana, 2019). Then, teacher training institutions should emphasize the teaching of instructional practices, student engagement and classroom management practices to the teacher trainees so as to improve their efficacies level (Sarfo et al., 2015).

These findings are in accordance with the result of Kurt (2016) that self-efficacy perception positively affects teacher leadership. Then it also supports OECD (2016) and Koşar (2015) that shows that supporting teacher professionalism has an significant and positive relationship with self-efficacy. Furthermore, the results sides with Cansoy et al (2018) which shows the teacher leadership are significant predictors of teacher professionalism. Our research has clear implications for theory and practice. Our research contributes to educational improvement regarding how to foster teacher professionalism by striving for developing self-efficacy and teacher leadership at the instructional level in classroom practice and further educational acitivity context. Therefore, the effort to fosters teacher professionalism is to enforce teacher leadership effectively and to maintance the teacher's self-efficacy. School leaders emerge teacher leadership by profesional learning community practice and facilitate the teacher professional networks so that their self-efficacy can be maintained. Through by profesional learning community also, educational practice can be improved, and more teachers are thus encouraged to collective and collaborative activities and reflection regarding their leadership to foster their professionalism. 
This research contributes ideas that can be used as knowledge and insight regarding managerial or management of an educational institution, building teacher professionalism, trust and teacher leadership in schools. Firstly, by considering the direct effect of self efficacy and teacher leadership on teacher professionalism, teacher professionalism is not just a formality but can be fostered by building proffesional learning communities for teachers and collaborating to support and develop student skills. The development of teacher professionalism is associated with the efforts of teachers to promote students to a higher level in school. In this regard, it may be considered important to provide teachers with a supportive working environment where they can act independently and can learn from each other as supportive colleague. Principals who strive to cultivate greater professionalism in the behavior of their teachers should demonstrate a professional orientation in leadership styles at the school level. The principal should provide opportunities for teachers to engage in leadership practices so that these leadership opportunities can foster teacher commitment. The principal's role in guiding teacher participation is a form of leadership opportunities offered to teachers. The principal selects certain teachers to be involved in leadership activities. Teacher participation in leadership activities can increase teacher commitment. If teachers and administrators are involved in joint decision-making, then teacher commitment can increase. Principals must not only support but also challenge teachers to develop the competencies necessary to accurately assess the needs of learners and to make wise instructional decisions in response to such assessments. A useful action in this regard involves developing professional skills for teachers to engage in co-teaching planning for example, by setting schedules to allow time for collaboration, communication, and peer coaching thereby creating a professional learning community in schools. While, the limitations of this study although the sample size of this study was adequate it limits generalization of findings, because only school teachers were selected and those were only from public schools in West Jakarta only. Also designing data collection with online distribution (google form) would be considered. Lastly, the pandemic condition might influence the teacher's self efficacy in online teaching practice and also the limitation of teacher leadership practice must be occurred.

\section{CONCLUSION}

There is direct effect of self efficacy and teacher leadership on teacher professionalism. Then self efficacy has affected directly to teacher leadership. Teacher professionalism is not just a formality but can be fostered by building proffesional learning communities for teachers and collaborating to support and develop student skills. The development of teacher professionalism is associated with the efforts of teachers to promote students to a higher level in school. In this regard, it may be considered important to provide teachers with a supportive working environment where they can act independently and can learn from each other as supportive colleague. Self-efficacy is significant for teachers' belief to learn and try new ideas and practices because it supports their orientation towards innovation and professionalism. School leaders have to facilitate teachers enacting highly developmental leadership behavior. Furthermore, along with a culture where teacher leadership is supported, some changes can be expected in teacher behavior to foster education quality as it is in schools where professional behavior is widespread. Teachers have the opportunity to learn and experiment with positive relationships among peers and share effective teaching practices. The principal can encourage the professional learning community 
to enhance teacher professionalism. Building teacher leadership culture needs to be implemented so that they can adapt to changes in external demands and the diverse needs of students. Furthermore, the government provides concrete forms of support for teachers to continue learning and developing their professional knowledge and implement policies that support teacher professional networks. Lastly, next research is recommended to conduct research into the holistic relationships between teacher professionalism and outcomes.

\section{AUTHOR CONTRIBUTION STATEMENT}

This research was conducted by Anisa Rara Tyaningsih and evaluated by Suryadi and Desi Rahmawati.

\section{ACKNOWLEDGMENT}

This research was made as part of requirements for the researcher to obtain a Masters Degree in Universitas Negeri Jakarta. This research was categorized as Individual Reasearch.

\section{REFERENCES}

Angelle, P. S., \& Dehart, C. A. (2016). Comparison and evaluation of four models of teacher leadership. Research in Educational Administration and Leadership, 1(1), 85119.https:/ / doi.org/10.30828/real/2016.1.4

Angelle, P., \& Teague, G. M. (2014). Teacher leadership and collective efficacy: Teacher perceptions in three US school districts. Journal of Educational Administration, 52(6), 738-753. https:/ / doi.org/10.1108/JEA-02-2013-0020

Avis, J., \& Orr, K. (2014). The New Professionalism: An Exploration of Vocational Education and Training Teachers in England. In S. Billett, C. Harteis, \& H. Gruber (Eds.), International Handbook of Research in Professional and Practice-based Learning (pp. 1099-1124). Springer Science+Business Media. Google Scholar

Boyaci, A., \& Oz, Y. (2017). Evolution of Teacher Leadership as a Challenging Paradigm in Rethinking and Restructuring Educational Settings. In I. H. Amzat \& N. P. Valdez (Eds.), Teacher Empowerment Toward Professional Development and Practices: Perspectives Across Borders (pp. 3-19). Springer Nature Singapore. Google Scholar

Bush, T. (2015). Teacher leadership:Construct and practice. Educational Management Administration $\mathcal{E} \quad$ Leadership, $43(5), \quad 671-672$. https:// doi.org/10.1177/1741143215592333

Cansoy, R., Polatcan, M., \& Parlar, H. (2018). Research on Teacher Self-efficacy in Turkey: 2000-2017. World Journal of Education, 8(4), 133. https:// doi.org/10.5430/wje.v8n4p133

Demir, K., \& Akif, M. (2015). The effect of organizational trust on the culture of teacher leadership in primary schools. Kuram ve Uygulamada Egitim Bilimleri, 15(3), 621634. https:// doi.org/10.12738/estp.2015.3.2337

Egener, B. E., Mason, D. J., McDonald, W. J., Okun, S., Gaines, M. E., Fleming, D. A., Rosof, B. M., Gullen, D., \& Andresen, M. L. (2017). The Charter on Professionalism for Health Care Organizations. Academic Medicine, 92(8), 1091-1099. https:// doi.org/10.1097/ACM.0000000000001561

Elkjaer, B., \& Brandi, U. (2014). An organisational perspective on professionals' learning. In International handbook of research in professional and practice-based learning (pp. 835-856). Springer, Dordrecht. Google Scholar 
Evetts, J. (2014). The Concept of Professionalism: Professional Work, Professional Practice and Learning. 29-56. https://doi.org/10.1007/978-94-017-8902-8_2

Fackler, S., \& Malmberg, L. E. (2016). Teachers' self-efficacy in 14 OECD countries: Teacher, student group, school and leadership effects. Teaching and Teacher Education, 56, 185-195. https:/ / doi.org/10.1016/j.tate.2016.03.002

Fairman, J. C., \& Mackenzie, S. V. (2015). How teacher leaders influence others and understand their leadership. International Journal of Leadership in Education, 18(1), 61-87. https:/ / doi.org/10.1080/13603124.2014.904002

Fogelgarn, R., Burns, E., \& Billett, P. (2019). Teacher-Targeted Bullying and Harassment in Australian Schools: A Challenge to Teacher Professionalism. In A. Gutierrez, J. Fox, \& A. C (Eds.), Professionalism and Teacher Education; Voices from Policy and Practice. Google Scholar

Habibi, B., Hartinah, S., Umam, R., Syazali, M., Lestari, F., Abdurrahman, A., \& Jauhariyah, D. (2019). Factor Determinants of Teacher Professionalism as Development of Student Learning Education at School of SMK PGRI in Tegal City, Indonesia. Journal of Gifted Education and Creativity, 6(2), 125-134. Google Scholar

Harris, A., \& Jones, M. (2019). Teacher leadership and educational change. School Leadership and Management, 123-126. https:// doi.org/10.1080/13632434.2019.1574964

Jumani, N. B., \& Malik, S. (2017). Promoting Teachers' Leadership Through Autonomy and Accountability. In I. H. Amzat \& N. P. Valdez (Eds.), Teacher Empowerment Toward Professional Development and Practices: Perspectives Across Borders (pp. 2141). Springer Science+Business Media. Google Scholar

Kemendikbud. (2019). Uji Kompetensi Guru. Neraca Pendidikan Daerah. Google Scholar

Klassen, R. M., \& Chiu, M. M. (2011). The occupational commitment and intention to quit of practicing and pre-service teachers: Influence of self-efficacy, job stress, and teaching context. Contemporary Educational Psychology, 36(2), 114-129. https:// doi.org/10.1016/j.cedpsych.2011.01.002

Koşar, S. (2015). Trust in school principal and self-efficacy as predictors of teacher professionalism. Egitim ve Bilim, 40(181), 255-270. https:// doi.org/10.15390/EB.2015.4562

Kurt, T. (2016). A model to explain teacher leadership: The effects of distributed leadership model, organizational learning and teachers' sense of self-efficacy on teacher leadership. Egitim ve Bilim, 41(183), 1-28. https:// doi.org/10.15390/EB.2016.5081

Lestari, S., Florentinus, T. S., \& Sudana, I. M. (2019). The Effect of Incentive, Principal Leadership, and Motivation toward Teacher Professionalism in Conducting Learning Activity at Vocational High Schools. 8(1), 34-43. Google Scholar

Lovett, S. (2018). Advocacy for Teacher Leadership. In Advocacy for Teacher Leadership. https:// doi.org/10.1007/978-3-319-74430-8

Ma'mun, M., \& Suryana, A. (2019). Instructional Leadership: the Effect of Teaching Self-Efficacy. Educational Administration Research and Review, 3(1), 35-43. https:// doi.org/10.17509/earr.v3i1.21715

Mulder, M. (2014). Conceptions of Professional Competence. In Stephen Billett, H. Gruber, \& C. Harteis (Eds.), International Handbook of Research in Professional and Practice-based Learning (pp. 107-137). Springer Science+Business Media. Google Scholar

Ninković, S. R., \& Knežević Florić, O. (2018). Transformational school leadership and 
teacher self-efficacy as predictors of perceived collective teacher efficacy. Educational Management Administration and Leadership, 46(1), 49-64. https:// doi.org/10.1177/1741143216665842

Odanga, S., Raburu, P., \& Aloka, P. (2018). Strategies for Enhancing Teachers' Selfefficacy in Secondary Schools. Asian Research Journal of Arts $\mathcal{E}$ Social Sciences, 6(2), 1-13. https://doi.org/10.9734/arjass/2018/38486

Öqvist, A., \& Malmström, M. (2018). What motivates students? A study on the effects of teacher leadership and students' self-efficacy. International Journal of Leadership in Education, 21(2), 155-175. https:/ / doi.org/10.1080/13603124.2017.1355480

Pineda-Báez, C., Bauman, C., \& Andrews, D. (2020). Empowering teacher leadership: a cross-country study. International Journal of Leadership in Education, 23(4), 388-414. https:// doi.org/10.1080/13603124.2018.1543804

Sachs, J. (2016). Teacher professionalism: Why are we still talking about it? Teachers and Teaching: Theory and Practice, 22(4), 413-425. https:// doi.org/10.1080/13540602.2015.1082732

Sarfo, F. K., Amankwah, F., Sam, F. K., \& Konin, D. (2015). Teachers' Self-efficacy Beliefs: The Relationship between Gender and Instructional Strategies, Classroom Management and Student Engagement. Ghana Journal of Development Studies, 12(12), 19. https://doi.org/10.4314/gjds.v12i1-2.2

Shaukat, S., \& Iqbal, H. M. (2012). Teacher Self-Efficacy as a Function of Student Engagement, Instructional Strategies and Classroom Management. Pakistan Journal of Science and Clinical Psychology, 9(3), 82-85. Google Scholar

Simons, P. R.-J., \& Ruijters, M. C. (2014). The Real Professional is a Learning Professional. In Stephen Billett, C. Harteis, \& H. Gruber (Eds.), International Handbook of Research in Professional and Practice-based Learning (pp. 955-985). Springer Science+Business Media. Google Scholar

Singh, S. K., Pradhan, R. K., Panigrahy, N. P., \& Jena, L. K. (2019). Self-efficacy and workplace well-being: moderating role of sustainability practices. Benchmarking, 26(6), 1692-1708. https:// doi.org/10.1108/BIJ-07-2018-0219

Suyatno, Wantini, Baidi, \& Amurdawati, G. (2019). The influence of values and achievement motivation on teacher professionalism at Muhammadiyah 2 high school Yogyakarta, Indonesia. Pedagogika, 133(1), 105-127. https:// doi.org/10.15823/p.2019.133.6

Tschannen-Moran, M. (2009). Fostering teacher professionalism in schools: The role of leadership orientation and trust. Educational Administration Quarterly, 45(2), 217247. https:// doi.org/10.1177/0013161X08330501

York-Barr, J., \& Duke, K. (2004). What do we know about teacher leadership? Findings from two decades of scholarship. Review of Educational Research, 74(3), 255-316. https:// doi.org/10.3102/00346543074003255

\section{Copyright Holder :}

(c) Tyaningsih, A., Suryadi, S., \& Rahmawati, D., (2021).

First Publication Right :

(C) Jurnal Iqra' : Kajian Ilmu Pendidikan

This article is under:

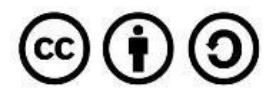

